LA-UA $-85-2272$

$$
\begin{aligned}
& \text { 111 05 } 0585 \\
& \text { CoNf } 85050 \cdot 2-45 \\
& \text { MASFER }
\end{aligned}
$$

TITLE THE WNR/PSR FACILITY - NEUIRON PHYSICS CAPABILITIES FROM

SUB-THERMAL TO $800 \mathrm{MEV}$

AuthoR(S) P. W. LIsowsk1, S. A. Wender, and G. F. Auchampaugh

The International Conference on Nuclear Data fur Basic: and Applied Science

Santa, Fe, New Mexlco, May 13-17, 1985

\title{
DISCLAIMER
}

\begin{abstract}
This report wan prepared at an acco'snt of work sponsored hy an asency of the United Sintea Government. Nelther the United Sinten (bovernment nor any agoncy therew, mor any of their employeen, maken sny warranty, expreas or implied, or ansumes any logal liability or responaibillity fis the accuracy, completenens, or usefulneas of any information, apparatun, product, of procesa diaclosed, or represonts that its une would not infringe privalely uwned rights. Reforence herein to any apocific commercial product, procean, or norvice hy trade name, irademark.

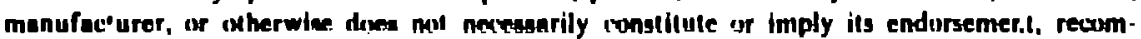
mendation, or fovoring by I e United Situles (hwernment or any agency therest. The views and opintions of authorn expressed herein do mot necesuarily alate of reflecil thuee of the United Siatea (iowernment or any inoncy therenf.
\end{abstract}


THE WNK/PSR FACILITY - NEUTRON PHYSICS CAPABILITIES FROH SUB - THERMAL TO 800 MEV

P.W. Llsowsk1, S.A. Hender, and G.F. Auchampaugh Los Alamos National Laboratory, Los Alamos, New Mexico 87545

\begin{abstract}
Abstigact The Weapons Neutron Research facllity (INR) is a versatile pulsed neutron cource used in a variery of rewearch programs ranging from fundanental neutron properties with ultra cold neutrons to aedlum energy charge exchange reaction studies. Here we describe the WNR facility and the Improvements presently in progress as the Proton Storage Ring (PSR) becomes operational.
\end{abstract}

\title{
INTRODUCTION
}

The Weapons Neutron Research facllity (WNR) $1,2,3$ has been operational since 1977 as a pulsed spallation neutror source at Los Alamos National Laboratcry. At the WNR a part of the $800 \mathrm{MeV}$ proton beam from the Clinton P. Anderson Meson Physicr Facility (LAMPF) ras been used used to elther provide white neutron souzce for Nurlear Physics and Condensed Hater research or for proton indjced reaction studies. At present the facilicy is bein's Glven significantly enhanced capabilities. Firat, the Proton Storage Ring (PSR), operational in 1985, will provide graatly Improved intersicy, time etructure, and repetition rate for neutron experinent. In the thermal and epithermal energy range. Second, an additinnal target area is belng conetructed for Nuclear Physics experiments which will take advantape of uultiplexed operation and forward angle flight.-patha to groatly onhance the fast-neutron flux over that presently avallable. Finglly, an ultra-cold neutron (UCN) source using neutrons from neutrino production target located south of the WNR/PSR complex is under development. In this paper we plan to review the WNR/PSR operating characteristics lllustrated by some recerit experimental results.

\section{FACILITX DEFEKLPTION}

The WNR/PSR liacllity is one of sovoral target areas located at LAMPF. LAMPF is an 800 MeV proton linac whlch elmultanoouely 
accelerates pulsed beans of $\mathrm{H}^{+}$and $\mathrm{H}^{-}$lone with a eacroscoplc frequency of $120 \mathrm{~Hz}$ and a acropulse length of approxiantaly 833 icroseconds. Because the flrst stage of acceleration operates at 201 reHz, the eccropulse has a sub-structure consisting of alcropulses which are separated by $5 \mathrm{~ns}$. The bean fron LAMPF to the WNR can be provided either as macropulses, sections of macropulses, or as macropulses which have been chopped to leave aicropulses with a animum separation of $360 \mathrm{ne}$. After acceieration, the proton bean is deflected from LAMPF to the UNR/PSR using a pulsed or kicker angnet which will operate at up to $120 \mathrm{~Hz}$.

The layout of the INR/PSR is shown in Figure 1 . Basically. there are four experiaental areas. Target-1, a high-current area which 1s fed by the Proton Storage Ring (PSR), Target-2, a lowcurrent. low-return room with an external proton beam capability. Iarget-4. aedium-current fast-neutron nucloar physics target aras. and an ultra-cold neutron source located above a neutrino physics production facility to the south of the WNR/PSR complax Nelther Target-4 nor the USN area are shown in Figure 1 .

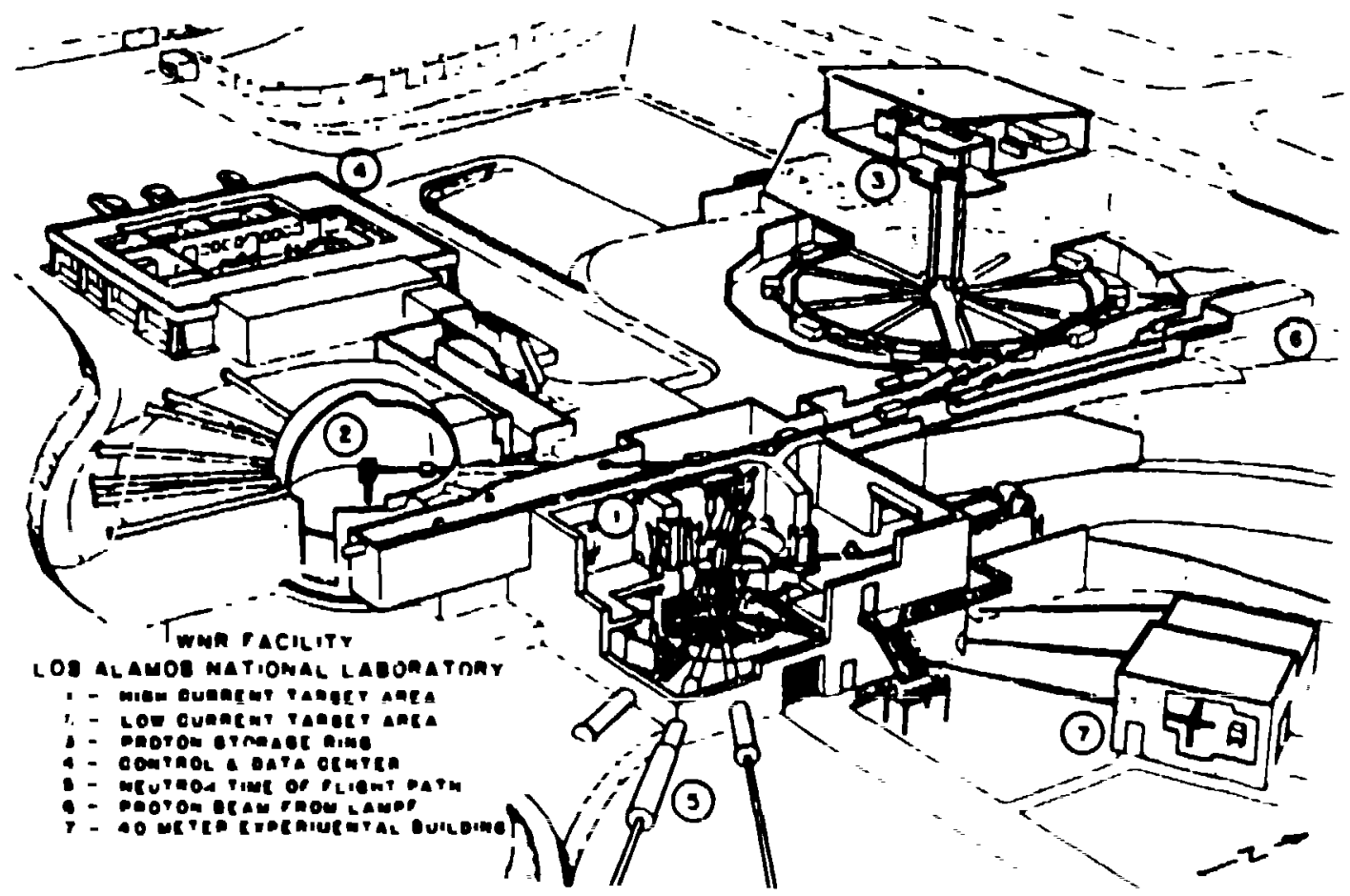

FIGURE I The leyout of ch.e WNR/PSR fac1licy. The beam from LAMPF enters from the rlght. The UCN and Target-4 areas are nor shown. but are located to the souch of the complex along the proton beam line from IAMPF and on an extension of the beam ilne into the low currert target. reapectively. 


\section{Brezen Storase Rins}

The pulsed proton bean delivered to the wNR directly fron LAPF Is too low In peak Intensity to allow the use of short pulses at a low enough repetition rate to be well aulted to condensed ateter and low-energy neutron phyelcs research. The PSR acts as a proton accumulator, converting the long linac pulses into appropriately short, very intense bursts at a low rapetition rats. This then allows tine-of-flight experiments with low-energy neutrons to be conducted with sufficient pulse epecing to avold frame overlap through the neutron energy range of 1rterest. Although fastneutron experiments will not use the PSR beam at the present $t$ ime, improvements to the LAPF chopper, bean transport system, and beam multiplexing systam as a resul of PSR tochnology have nade a dramatic increase in the beam current avallable for fast-neutron physlcs. This may be seen in Table 1 which compares proton beam operating conditions for the UNR with and without the PSR.

TABLE 1 LAMPF and INIR proton beam characteristics

\begin{tabular}{|c|c|c|c|c|c|}
\hline & LAMPF & $\begin{array}{l}\text { PRE-PSR } \\
\text { MACRO-PULSE } \\
\text { WODE }\end{array}$ & $\begin{array}{l}\text { PRE-PSR } \\
\text { UICRO-PULST } \\
\text { MODE. }\end{array}$ & $\begin{array}{l}\text { POST- PSR } \\
\text { MACTO-PULSE } \\
\text { MODE }\end{array}$ & $\begin{array}{c}\text { POST-PSR } \\
\text { YICWO-PULST } \\
\text { MODE }\end{array}$ \\
\hline PRoTONS PULSE & $52 \times 10^{13}$ & $2.8 \times 10^{11}$ & $50 \times 10^{7}$ & $52 \times 10^{5}$ & $30 \times 10^{\circ}$ \\
\hline PQLSE DIMTH & $833 \mu s$ & $5 \mu s$ & 200 ps & 270 ns & $200 \mathrm{ps}$ \\
\hline SEPETITION RATE & $120 \mathrm{~Hz}$ & $120 \mathrm{~Hz}$ & $10000^{\circ}$ & $12 \mathrm{~Hz}$ & $58000^{\circ}$ \\
\hline $\begin{array}{l}\text { PAOTONS SDCONA } \\
\text { WEAACE }\end{array}$ & $635 \times 10^{19}$ & $34 \times 10^{17}$ & $50 \times 10^{11}$ & $E 25 \times 10^{14}$ & $18 \times 10^{13}$ \\
\hline $\begin{array}{l}\text { WERACE PROTOM } \\
\text { CLRRENT }\end{array}$ & $1 \min$ & $\therefore 4 \mu A$ & $B O \mathrm{nA}$ & $100 \mu A$ & $28 \mu A$ \\
\hline
\end{tabular}

During PSR/NNR operiltion. the $\mathrm{H}^{-}$bean 1 s deflected from the linac by a pulsed magnet into a drift tube leading to the HNR/PSR complex A second pulsed lagnet can then deflect the beam into the PSR In order to traniport the beam into the PSR a otripier magnet is used to selectively remove one electron cunverting the $\mathrm{H}^{-}$to $\mathrm{H}^{\circ}$ with high efficlency allowing the beain to enter the YSR ring through a magnet. Beim is then accumulated and raturned to line-D aftel a foll etrippir which converts the beam to $\mathrm{H}^{+}$for transport to the WNR targe:

Constructiol of the PSR was begun in early 1982 and the complex is currently in operation. A progrestue currint increase Is planned with up to 100 microsmperes planned for the UNR ta:ge: by the full of 1986 
P. U. LISOUSKI, S. A. UENDER, AND C. F. AUCHAMPAUGH

\section{Target-1}

The high-current target area has recently been upgraded 4 to eccept as auch as 200 alcroamperes of $800 \mathrm{MeV}$ proton bean. Here the target-noderator and flight path geowetry has been optinized to use the PSR bean structure of $270 \mathrm{~ns}$ at $12 \mathrm{~Hz}$ to produce an Intense thermal and epithermal source, useful for both condensed metter and low-energy neutron nuclear physics studies.

This area has a split target-moderator-reflector (TRR) assembly located in the center of $2-\mathrm{h}$ high, 1-a diam. cylindrical vold, and surrounded by a 4.2-b thick lron and laminated Iron-concrete blological shield. The TRR geonetry will eventually permit up to 17 neutron flight paths to operate simultaneously with six separately optimized moderators. As shown in Figure 2 the neutron flight pacha vieu the noderators at $90^{\circ}$ to the incident proton beam. and the target is split so that experiments do not view the cencral neutron-producing target directly. thus reducing fast neutron background. Initial mocierators will include two conventional polsoned amblent water

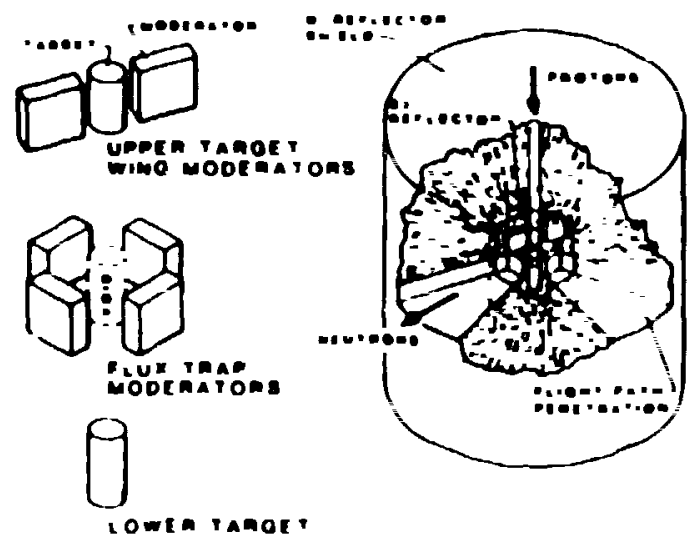

FIGURE 2 The WNR high-current IMR configuration. The present arrangement has twelve flight paths viewing the flux-trap moderators. Future flight paths would view wing moderators which would be installed in the upper target position

moderators. $20^{\circ} \mathrm{K}$ liquid $\mathrm{H}_{\bar{c}}$ culd moderator. and a highresolution mcderator decoupléd at $3 \mathrm{GV}$ which has been optimized for eplthermal neutron experiments. For the amblent water moderatore preliminary calculations of neutron incensicies and pulse widths for the flux-trap geometry are shown in Figures 3 and 4. With this cholce. the spectrum is Maxwell-Boltzman at thermal. but is proportional to lit. at opithermal energies. In addition. the pilse width 1 s inversely proportional to velocity at eplthermal energles so that IIme-of-Flight (TOF) experimerita have constant onergy resolution in that energy regime.

\section{Target-2}

The existing low-current target. labellod as target-2 in Figure 1. 1. shlelded for up to 100 nanoamperes of proton beam. This roor. 1. designed to reduce roon return by having a low-mase floor and a 6-meter wall-to-center epacing Because of the flexibliticy of design. many different experiments have been performed in this 
ENR/PSR FACILITY - NEUTRON FIYSICS FROA SUB-IHERAL TO 800 MEV

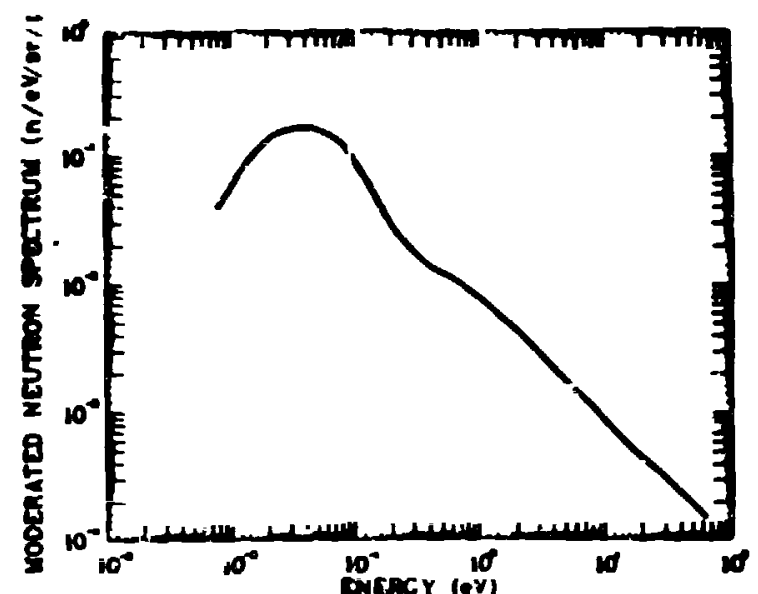

FIGURE 3 Calculated neutron spectrum onteced et $90^{\circ}$ to the noderator surfaco fron the UNR flux-trap TMR

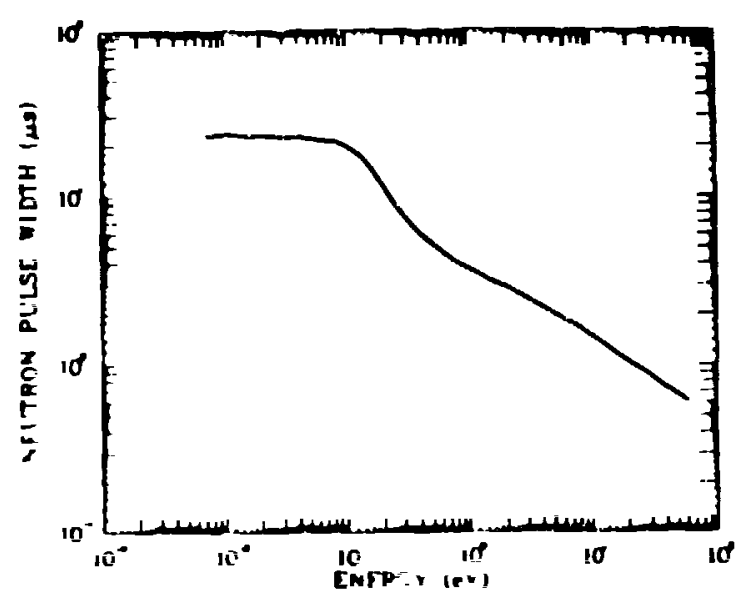

Figure 4 Calculated pulse widhs of neutrons enitted from the WNR flux-trap TMR.

area Most recently. theorecical predictions of target-moderator reution oulput for the upgraded WNR/PSR target gystem haye been tested and a varlety of proton-induced reaction studies have beeri carried out.

The target-moderator measurements ${ }^{5}$ were performed using a vertical. well shlelded $5.6 \mathrm{~m}$ flight path located in the center of Target-2. The neutron decection scheme for those experiments has been to use a $\mathrm{BF}_{3}$ proportional countgr to detect moderated neutrons in the Ine-of-jight and He counter to measure the neution intensity and rime profile by scatering from a pyrolytic graphite crysical.

Measurements of fast neutron spectra using the chopped. or mficropulse beam heve been made using a target changer placed at the cencer of the room vith neutron detectors positioned outside on flight pathe of approximately 30 metors. Thase experiments have typirally been performed to teat Intranuclear Cascade calculations. For such experiments angular distributions at angles of $7.5^{\circ}, 15^{\circ}, 30^{\circ}, 45^{\circ}$. and $60^{\circ}$ are poselble. Shown in 
P. W. LISOWSKI, S. A. MENDER, AND G. F. AJCLIAMPAUGH

Figure 5 are double differential cross sectiona for the $238 \mathrm{U}(p, \times n)$ reaction at anglea of $7.5^{\circ}, 15^{\circ}$. and $30^{\circ}$ re=ently obtcinad ${ }^{6}$ using Target-2.

By renoving the bean pipe and allowing the proton bean to pass through the air. It is possible to have an externsi proton beam in the center of the room for varlous test set;ups and irradiations. For example, beam-pilse timing tests which measured the proton micropulse widch to be 200 ps FWHM were performed uy measuring the time spread of the cherenkov light from a lucite rod coupled to a photodiode inserted in the beam in this area.
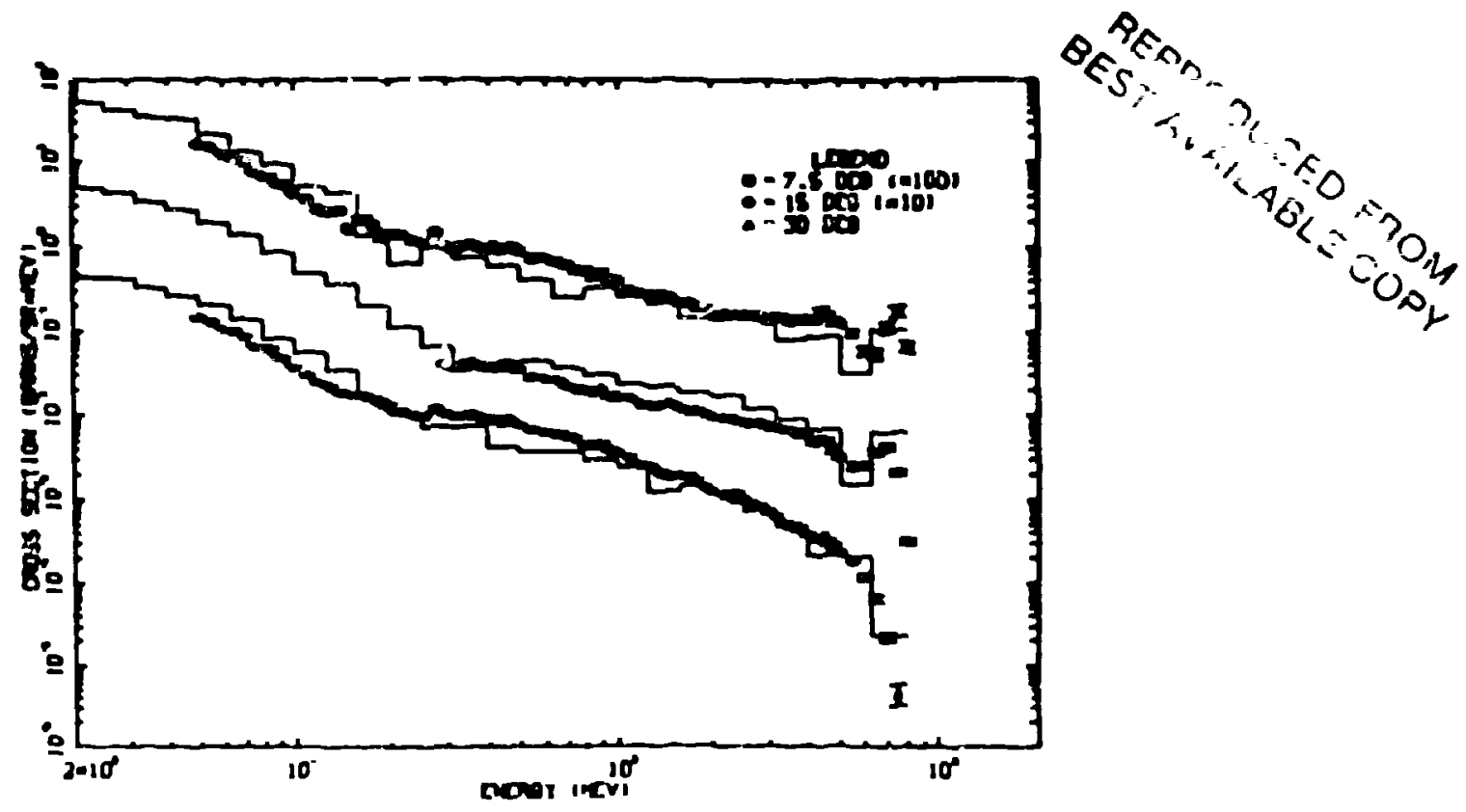

FIGURE 5 Double differential cross sections for ${ }^{238} \mathrm{U}(\mathrm{p} . \mathrm{xni}$ at 800 MeV obtained using Target-2. The histograms are Intranuclear Cascade calculations

\section{Iarget-4}

In order to provide a source of fast neutrons for Nurlaar Physics experiments. Anew white source facility is under construction at the WNR/PSR. A layout of this area 1 s shown in Figure $G$ and can te seen to be located on an extension of the beam transport systen for Targe: -2 . In this farllity. there are three inpurtant features. First. the flexiblifity of the existing Jarget-2 arrangement will be maintilned by using an $8^{\circ}$ bencing magnet to elevate the new white-source flight paths above thuse of Target-2. as illustrated in Figure 7 . Second. Aigh-resolution amall-angle (b.n) experimental factlity located along line-D at whr. which had to be mrived because of conflict wt th the Neutrino Facllity. can te 
VIR,PSR FACILITY - NEOTROA IHYSICS MOH SUB-THERYL TO 800 VLV

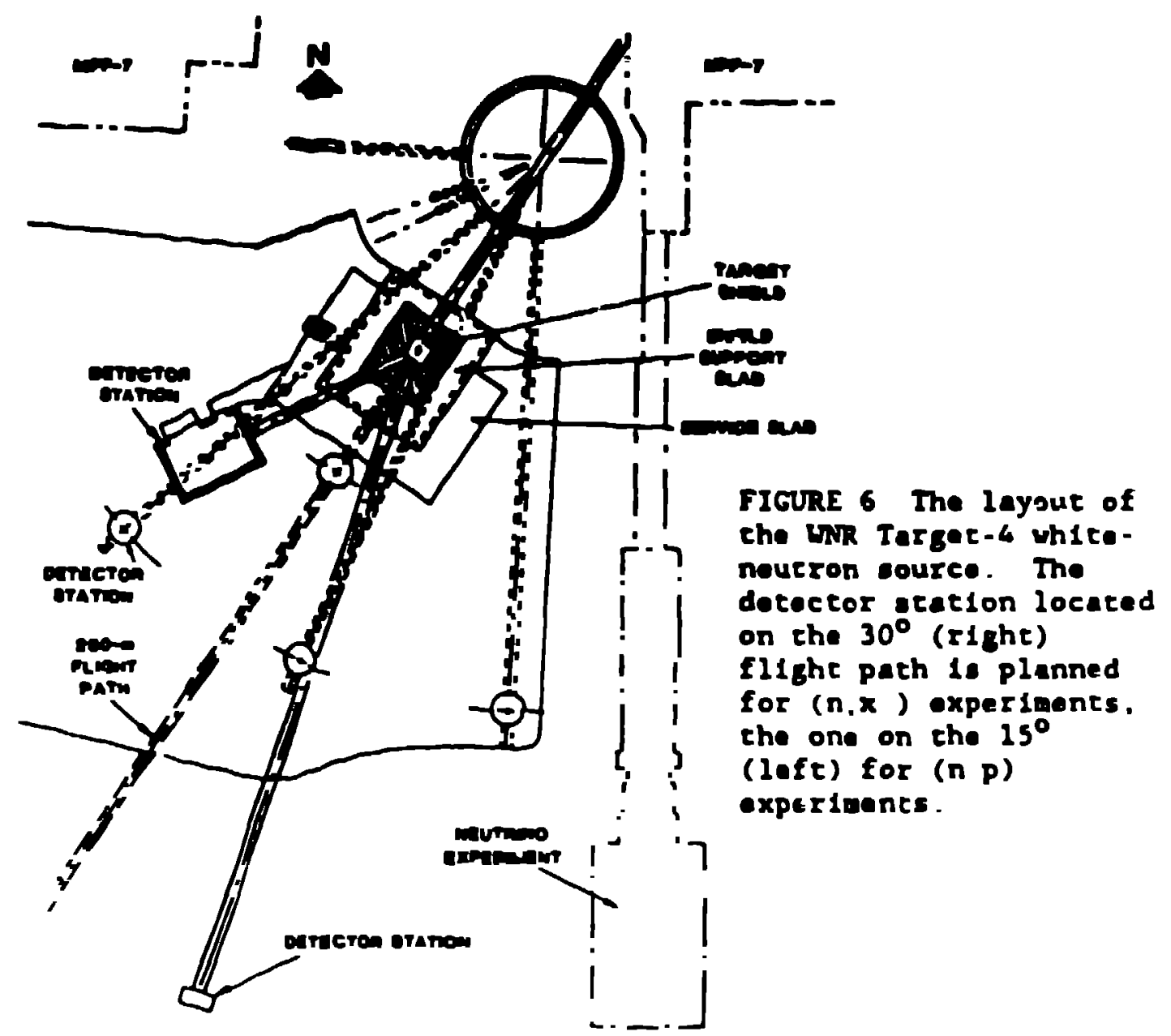

operaced simultaneusly with the whice source in this area.

Third. the neutron flight paths for the new facility viow the production target at forward angles instead of $90^{\circ}$ as in the old Target-1 arrangement, thus providing a source extending to nearly Būi MeV with greatly Increased noutron Intenalty above about 20 ME!.

Target-4 will have seven flight pache viewing the production zarget at angles ranging from $15^{\circ}$ to $90^{\circ}$. The noutron wource strengtha at angles of $30^{\circ}$ and $112^{\circ}$ are shown in Figure 8 . Thgse results were computed from measured thin-target crosa mections for $15-\mathrm{cm}$ thlck targecs. Comparing $30^{\circ}$ and $112^{\circ}$ reaules for copper show that the cource etrength for foruard angles ramaing nfarly constait to $500 \mathrm{MeV}$; furthernore. there 1s sore than an order of magnitude nore intengity for noutrons with energies above $60 \mathrm{meV}$. The solid curve In Figure 8 gives the yield for the nost intense laboratory source of moyoenergetic seutrone, the $H(t, n)$ reaction. Here the calculation was perforned with a pulsed beam current of 0.5 alcroampere of tritiun bean. The more 


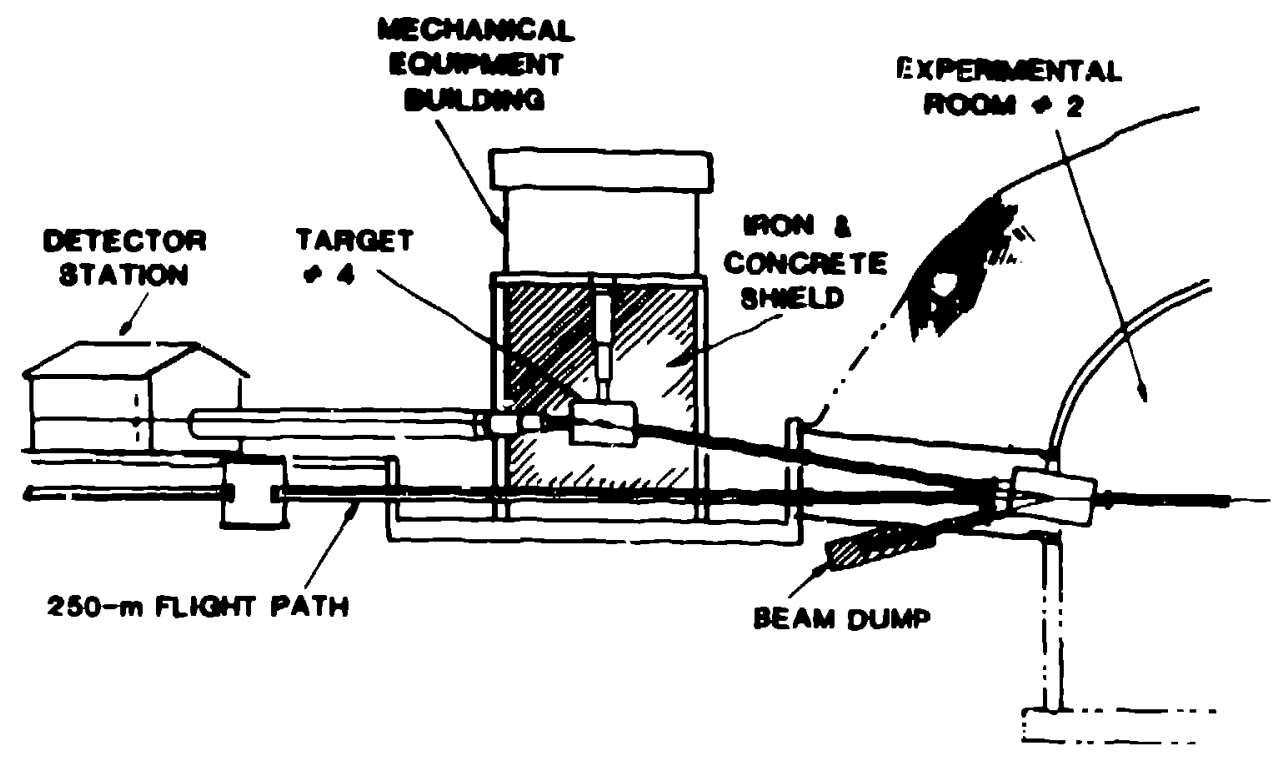

FIGURE 7 A side view of WNR Target-4. The proton beam is deflected $8^{\circ}$ up into Target-4 from Target-2. The target changer for high resolution $(p, n)$ experiments is located in the magnet. For measurements at angles greater than $8^{\circ}$, the proton beam is bent down into the beam dump.

common $14 \mathrm{MeV}$ source, the d-T resonance reaction would yleld about $10^{8} \mathrm{n} / \mathrm{s} / \mathrm{sr} / \mathrm{MeV}$. For cumparison with an existing white cource faclilty, Figure 9 shows, the number of neutrons $/ \mathrm{cm}^{2} / \mathrm{sec}$ versus reutron energy for ORELA 10 and WNR Target-4. In this comparison, similar to that in Reference 3 , the overall timing for detected neutrons was taken to be 1 ns for WNR and $5 \mathrm{~ns}$ for ORELA. The numbers in parentresis give the number of pulses and the flight path needed to maintain an energy resolution of $8.8 \times 10^{-4}$. Other parameters used in the calculation are given in Table 2.

Target-4 conatruction ia planned tc atart in late May of 1985 with three flight paths to be implemented in time for experiments to be performed during the 1986 LAMPF Cycle. The three flight paths to be implemented are a 250-m flight path for high resolution medium energy $(p, n)$ reaction studies, a $15-m$ flight path at $30^{\circ}$ for fast-neutron capture and gamma-production experiments, and a 65-m flight ppth a $^{\circ}$ for (n,p) experiments. The $(p, n)$ and $(n, x y)$ experimental $1,12,13$ have alroady produced unique nuclear physics information from initial experimenta carried out at WNR Figure 10 shows cross pection angular diatributione for ${ }^{12} \mathrm{C}(\mathrm{p}, \mathrm{n})$ at three angles. Il These spectra 1llustrate the ability of experinenta at WNR to cover a broad range of nuclear excitation. The pectra on the right aliow a high-resolution plot of the low momentum-tranafer region showing for the first tine for $(p, n)$ reactions at $800 \mathrm{MeV}$, a resolved nuclear tranation. The epectra on the left are low resulution 
WNR/PSR FACILITY - NEUTROA PHYSICS FROM SUB-THERYAL TO 800 MEV

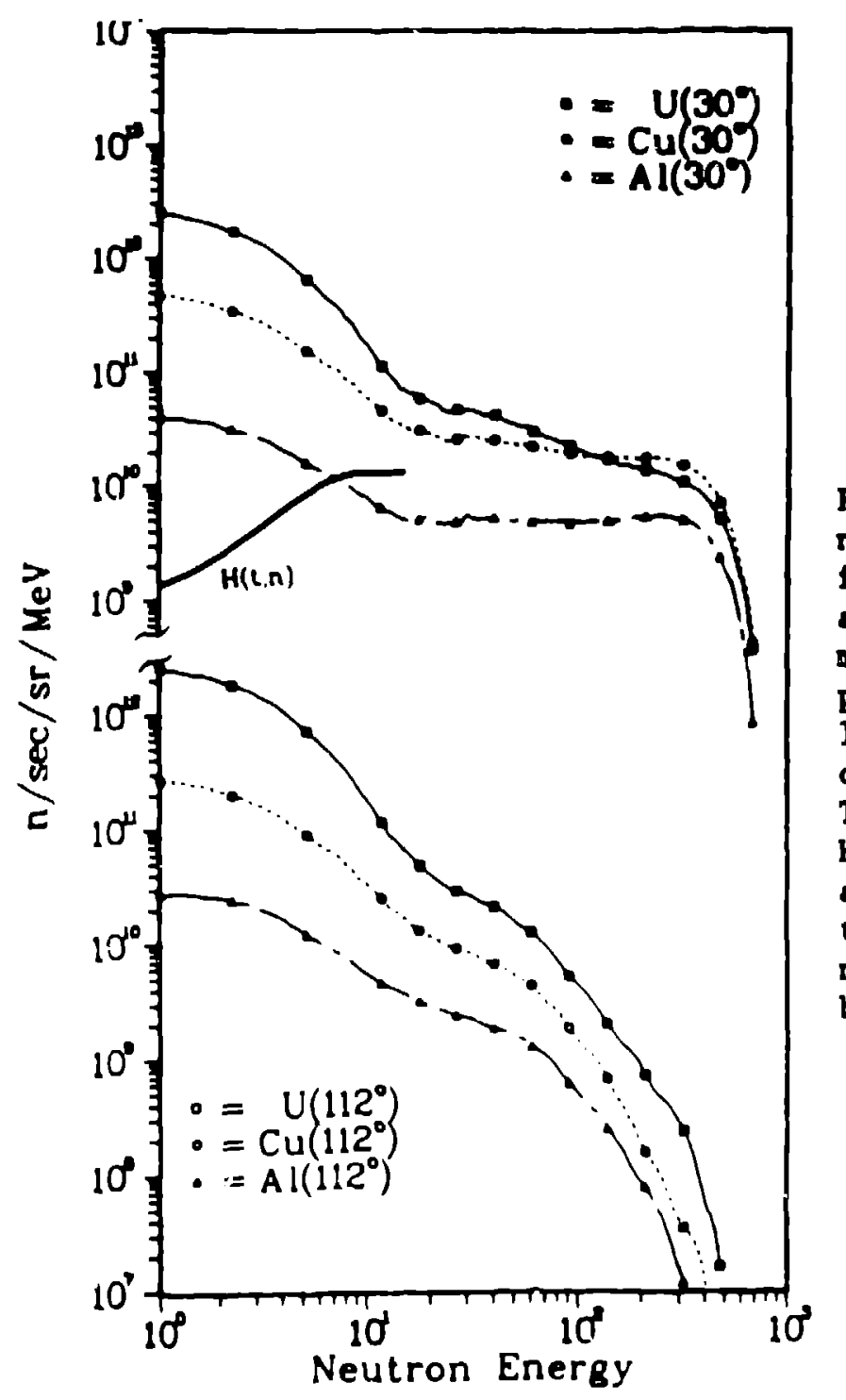

FIGUKE 8 Calculated noutron source trengths for angles of $90^{\circ}$ (top) and $112^{\circ}$ (bottom) for 1 alcroampere of $800 \mathrm{MeV}$ proton beam incident on $15-\mathrm{cm}$ thick targets of difforent materials. The solld curve labelled $H(t, n)$ ia calculated for an 0.5 microampere tritium beam producing a monoenergetic neutrun beam

plots of the came data but extending to the delta-production region near $1050 \mathrm{MeV} / \mathrm{c}$.

\section{Ultra Cold Neutron Seurce}

Located to the south of the WNR/PSR complex as seen in Figure 6, there is a neutrino experiment. The beam dump for this area was deslgned to be a very efflclent thermal neutron sourco. Here, one $\mathrm{Hz}$ of the beam used to produce neutrinos in a carbon target 1 a planned to be steered directly onto a tungeten beamstop. A vertical neutron flight path, Installed and tooted in 1984 permita thermal neutrone from an adjecent moderator to be extracted and used. The UCN are then produced by Doppler ahifting 400 meter/second neutrons by Bragg reflection from a ming crystal. The apparatus for thls was drveloped at Argonne National 
P. H. LISOUSKI, S. A. WENDER, AND G. F. AUCHAMPAUGH

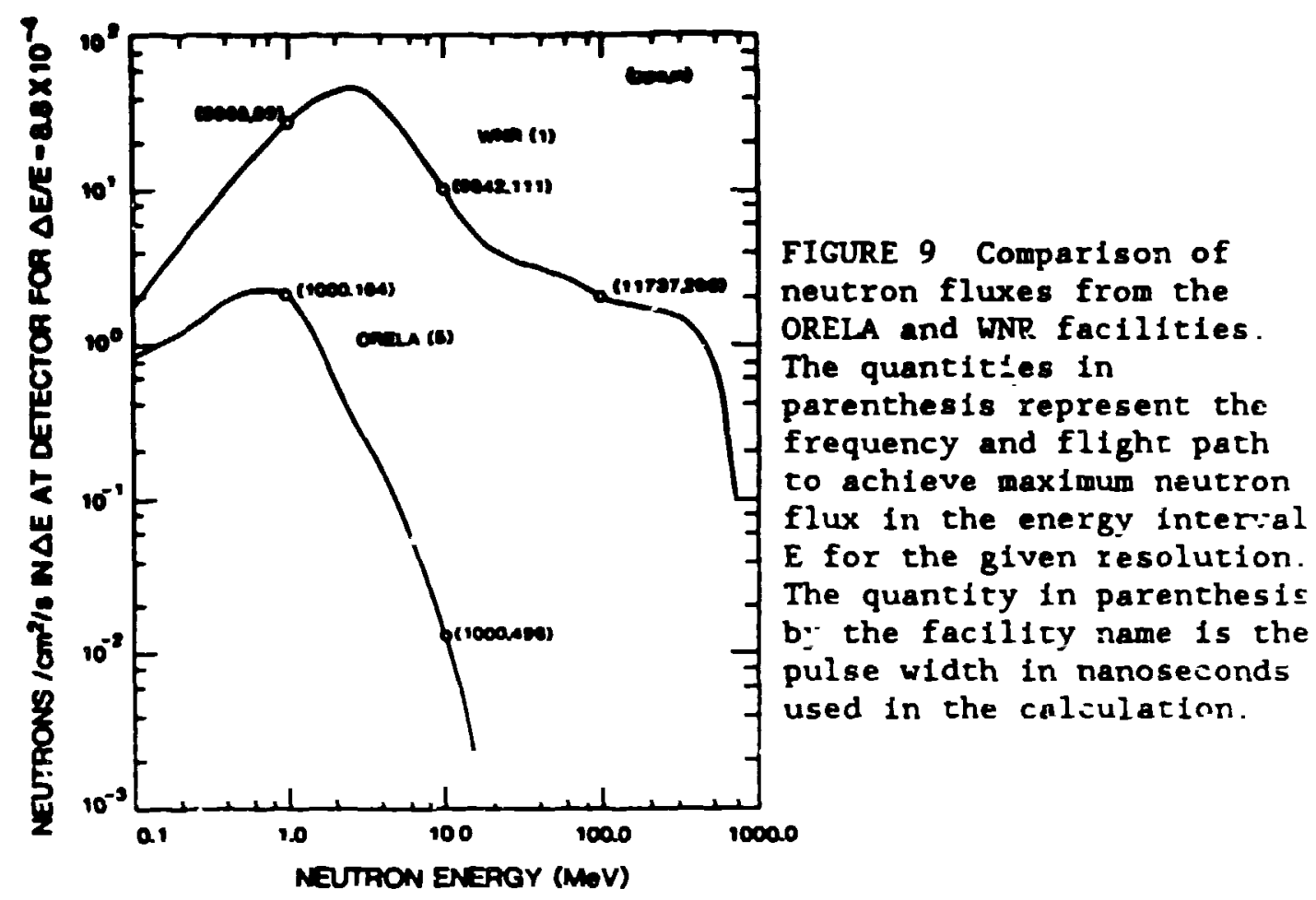

TABIE 2 Machine parameters used to calculite Figure 9

\begin{tabular}{|c|c|c|c|}
\hline FACILITY & $\begin{array}{l}\text { PULSE FREQUENCY } \\
\text { (dz) }\end{array}$ & $\begin{array}{l}\text { AVERAGE BEAM } \\
\text { CURRENT OR POTER }\end{array}$ & TARGET \\
\hline ORELA & 1000 & $10 \mathrm{kw}$ & Th. $\Delta=22 \mathrm{~cm}$ \\
\hline WNR & -25000 & $<2 \mu A$ & $\begin{array}{l}=15-\mathrm{cm} \text { LONG } \\
=30^{\circ}=22 \mathrm{~cm}\end{array}$ \\
\hline
\end{tabular}

Laboratory and is in place at the WNR. Figure 6 shows a layout of the neutrino area with the UCN flight path near the center.

Alchough several experiments have been proposed for the UCN. a measurement or lowering of the $11 \mathrm{nlt}$ of the magnitude of the electric dipole moment (EDM) of the neutron is the most important. For EDM measurements of the type pianned here the accuracy of the result depends on the number of neutrons stored in a bottle. For this experiment the number stored asymptctically approaches the peak neutron flux. At spallation sources such as WNR, the peak flux is expected to be an order of magnitude betcex than from any reactor yet bullt. A further advantage will come from running a cold moderator more closely coupled to the spallation source than 1a possible in a reactor, thus increasing the efficiency of neutron moderation. A density of $120 \mathrm{UCN} / \mathrm{cm}^{3}$ is expected if the PSR beam 1s used with an optimized UCN bottle. This may be compared with the density of $005 \mathrm{UCN} / \mathrm{cm}^{3}$ reported in 1984 by Pondlebury ot al. 14 
WNR/PSR FACILITY - NEUTRCN PHYSICS FROM SUB-THEPMAI. TO $800 \mathrm{MEV}$ ${ }^{1} \mathrm{C}(\mathrm{p} . \mathrm{n}) \quad \mathrm{T}_{\mathrm{p}}=800 \mathrm{MeV}$

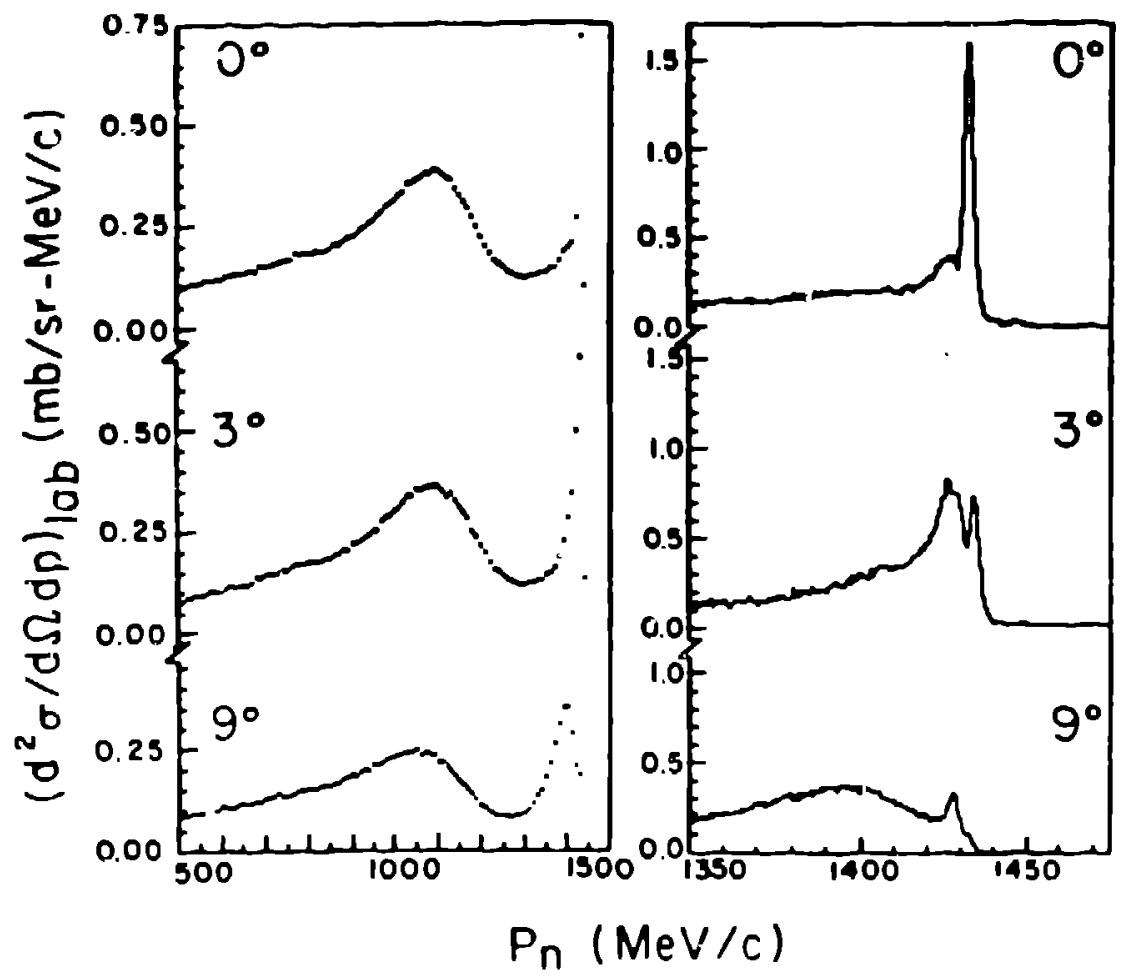

FIGURE 10 At left: low resolution ${ }^{12} \mathrm{c}(p, n)$ data showing the dialta-production region near $1050 \mathrm{MeV} / \mathrm{c}$. At right is an expanded spactrum in the region of the ground-state transition.

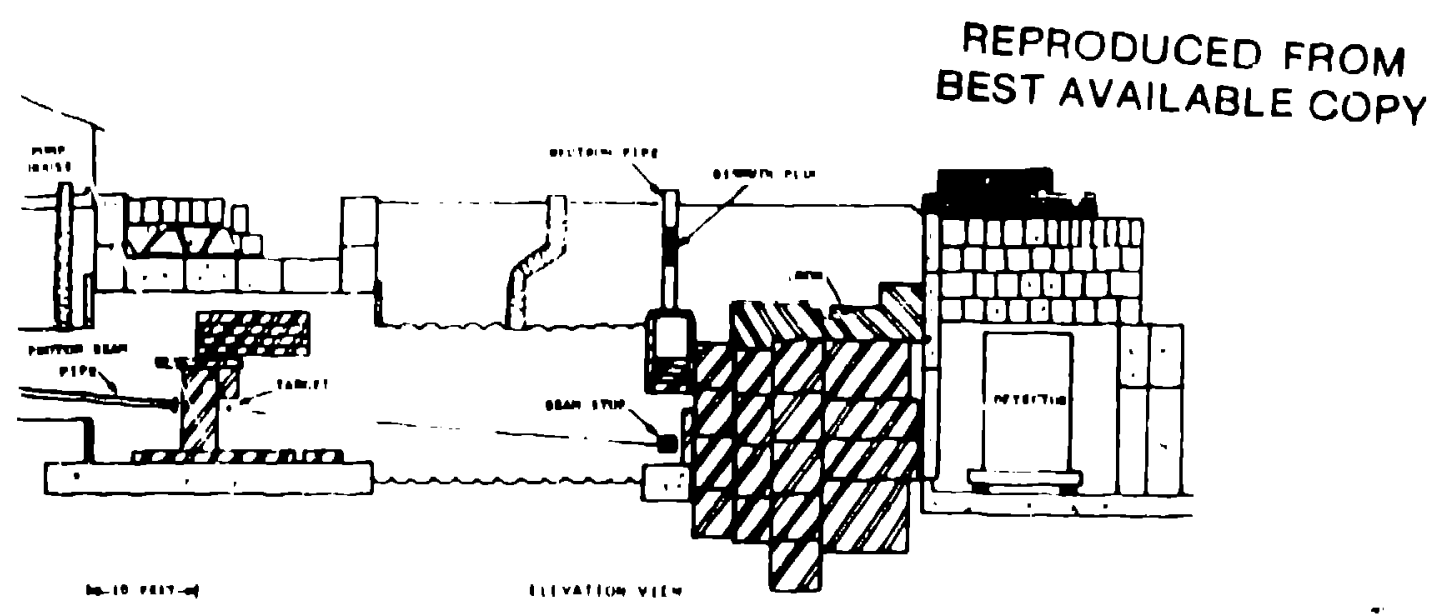

Figure 11 Elevation view of the neutrino facllity locatod at the WNR. The neutron flight path to the UCN apparatid id indicated by the label NEUTRON PIPE near the center of the drawing. 
P. W. LISOUSKI, S. A. WENDER, AND G. F. AUCHAMFAUGh

Suger:- :

The WIR/PSR Facility will be operational during 1985 for Condeneed Matter researck. the most intense puleed-neutron source in the world. By epring of 1986 the fast-neutron capabilities vili be greatly onhanced with the addition of a multi-use white-neutrin source for sasurowents in the 1-500 MaV range, and 250-n flight path for $(p, n)$ reaction studiles. Thls facility will be heavily ised by the Los Alamos ataff for a variety of basic and applied research, but proposal from outside collaborators or groups wishing to conduct experimeits at the WNR/PSR are encouraged.

\section{REFERENCES}

1. G.J. Russe11, P.A. LInowski, S.D. Howe, N.S.P. KIng and M.M. Moler, in Nuclear Ren for Science nd Technology. Inceractonal Conforence, Antwerp, 1982 , odited by $K$. Boeckhoff (Rr:1del, Dordre1ch), P. B31.

2. G.J. Ruasc1?, Los Alamos National Laboratory Report, LA-UR84.778 (1983).

3. G.F. Auchawpiugh in Crogs Sections for Technology, Internationa] Conference, Knoxvi110, 1980, edited by J.L. Fowler, C.H. Johnson, and C.D. Bowman, (NBS Speclal Publication No. 594), p. 920.

4. S.J. Russe11, Los n? mos National Laboratory Internal Report, TN-GJR/P9.006 (1983).

5. G.J. Russell, M.M. Meier, Y. Robinson, and A.D. 'Taylor, in Broceedings of the Fifth Meetho of the International Collaboration on Advanced Neutren Sources (ICANS-V), ¿ruelich, 1981

6. M. M. Meler, D. Holtkamp, G. L. Moigan, H. Robinion, G. Russe 11, R. Whltaker, W. Amlan, and N. Paul, In International Conterence on Nuclear Date for Basic and Apolied Science, Santa Fe, 1985, contribution JC23.

7. Brofect Summary Los alames Nacional Laboratory Support Brogram, EGG 1183-2458, 44 (1982).

8. S. D. Howe Ph.D Thes1a, University of Kanasa, 1975 (unpublithed).

9. M. Droeg Los Alamos National Laboratory Memorandum P-3/85-247 (1985)

10. E. R. Rae and W.M. Good, In Expertmentel Neutron Regoriance Sproirnscopy, edited by J. A. Harvey (Academlc Prass, New Yor:., 1970), Chap. 1, PP. 1-99.

11. N.S.P. KInE, P.W. Llsowak1, G.L. Morgan, P.N. Cra1g, R.G. Jepposen, D.A. Lind, J.R. Shepard, J.L. Ul1man, C.D. Zafiratos, C.D. Coodman, and C.A. Goulding, to be publiahnd. 
WNP,PSR FACILITY - NEUTRON PHYSICS FROM SUB-THERMAL TO 800 HEV

12. S.A. Wender, and G.F. Aucharpaugh, Intermatlonal Gonforence on Nuclear Dete for Pure and Apnlled Sclence, Santa Fo, 1985, contribution JB08; C. R. Gould, J. Dave, G.E Mitchell, P. Ranakrishnan, G.F. Auchampaugh S.A. Wonder and R.C. Little, 1bid. contribution AD04.

13. S.A. Wonder and G.F. Auchampaugh, in The Eifth International Symposium on Capture Gamm-ray Spectroscopy and Belated Teplae Knoxvilie, 1984, odiced by S. Raman (American Institute of Physics, New York), P. 483.

14. J.M. Pendlebury et al., Phys. Lett. 136B, 327. (1984). 